УДК 339.138

DOI: 10.18523/2519-4739.20205.1.113-117

M. Synytsya

\title{
THE COMPETITIVE POSITION OF THE COMPANY: THE CONTRADICTIONS OF ESSENCE AND NEW APPROACHES
}

This paper analyses some key definitions and ideas of brand positioning among scientists for the recent 40 years. There are a lot of contradictions in the meaning of this concept that complicates the development of the firms' full-scope positioning strategy and creates confusions in scientific studies.

The paper attempts to describe the importance of a complex approach to competitive positioning of the enterprise which relies not only on marketing positioning of its products or itself but also on positioning relative to competitors and current (or possible) employees. It is also shown that behavioral factors (including cultural variations) should be considered in the positioning strategy.

The article proposes a comprehensive approach to the classification of positioning strategies based on the systematization of criteria for creating excellent characteristics of a product, brand, and enterprise.

The paper concludes with several suggestions on the modern view of the competitive positioning concept, where the subject of competitive positioning was not only the product but also the enterprise that produces it. As a result of this research, it is proposed to join competitors and employees of the company to the objects of competitive positioning, which would result in the emergence of the concept of behavioral competitive positioning.

Keywords: marketing, competitive positioning, strategy, competitiveness, brand, behavioral aspects.

JEL classification: D03, D21, M31, M37

Introduction and research problem. In nowadays market conditions, one of the key factors of success is the right positioning not only of the product but also of the company. The positioning becomes one of the main concepts of strategies of the brand promotion, product placement, and the image of the firm. In the classical theory of marketing, positioning is considered as the creation of a certain position among the competing goods for a product, a kind of niche that would be reflected in the hierarchy of values formed in the minds of a potential buyer. However, along with the market positioning, there is an active usage of the concept of competitive positioning in recent studies that is not exclusively associated with marketing.

Recent publications analysis. During the past 40 years much more information of the problem of companies' positioning was reflected in a large number of studies and books by well-known western scientists, first of all, the authors of the corresponding concept - Al Ries and John Trout and their followers F. Kotler， D. Aaker， N. Piercy， G. Hooley. Also studies from some domestic scientists are reviewed, for example, G. L. Azoev, and P. Chelenkov.

Unsolved parts of the problem. In domestic literature, the notion of competitive position is often equated with competitiveness, and the object of positioning is narrowed to the products of individual manufacturers. Moreover, the behavioral factors are mostly dropped out of sight.

Research goal and questions. The main research goal is to clarify the essence of positioning as a category and generalizing approaches to positioning taking into account current factors.

Main findings. For the first time, the concept of positioning was proposed by Trout and Ries. In their opinion, positioning is the creation of a certain position among the competing goods for a product, a kind of niche that would be reflected in the hierarchy of values formed in the minds of a potential buyer (Ries \& Trout, 2001, p. 27).

In modern scientific literature, there is no consensus on what exactly the positioning of brand, product or a company is. For example, according to Aaker, positioning is the face of a business strategy that demonstrates the company's desire for its perception (compared to competitors and the market as a whole) to buyers, employees and partners (Aaker \& McLoughlin, 2010, p. 238). According to Doyle, positioning is a marketing activity in the selection of target segments, which sets the areas of competition, the choice of distinctive advantages that determine the methods of competition (Doyle, 2006, p. 157). According to Kotler, positioning is a 
set of measures, according to which one product in relation to competing products has its own place, different from other companies and advantageous for the company in the minds of target customers, the way in which consumers identify one or another product according to its most important characteristics (Kotler, 2011, p. 105).

These statements are not mutually exclusive. However, in order to facilitate the positioning of products, brands and enterprises themselves in practice, there is a theoretical coordination of the positioning and the development of common standardized approaches to the classification of positioning strategies and approaches to their complementary and mutually exclusive needs is needed.

Along with the market positioning, numerous studies have attempted to explain the concept of competitive positioning in recent years. For example, according to Hooley and Piercy, the competitive positioning "recognizes the influence of every aspect of the market offer, important from the point of view of customers to create a distinctive value" (Hooley \& Piercy, 2011, p. 338). The concept of competitive position is often used as a synonym for the competitiveness of the enterprise. Azoev and Chelenkov argued that the competitive position of the enterprise is a differentiated characteristic of its competitive success in the market: "One of the most important directions of the strategy definition is its connection to the competitive status (competitiveness, in other words) of the company. In this regard, the development of four competitive positions with respect to the market outsider, firms with weak and strong competitive positions and market leader deserves attention." (Azoev \& Chelenkov, 2006, p. 177).

Summarizing the results of the predecessors, Kotler (2011, p. 230) carried out a number of investigations into the brand positioning and attempted to differentiate the types of positioning. He identified the following types:

- attributive;

- positioning of advantages;

- consumer;

- competitive;

- quality / prestige positioning;

- price positioning.

However, Prymak highlighted that the main problem of the classification of all positioning strategies is the lack of common principles by which they can be differentiated, hence the confusion about which strategies are the main ones and which are secondary; which are strategies, but which are sub-strategies, and thus it is not clear how positioning strategies can be coordinated with each other, which are mutually complementary, mutually exclusive (Prymak, 2012, p. 15). In addition, such a positioning strategy as "positioning relative to competitors", which is allocated to a large number of authors, cannot be called a strategy at all, as the allocation among competitors is achieved through the timely application of one or more other strategies, such as positioning for benefits or functional features of the product. Most likely, this is a strategic direction of distancing from competitors, which should be the basis of the activities of any enterprise that operates under market conditions. And this direction should be realized in actions aimed at outstripping competitors, separating from them and complicating their actions.

Smolin (2018, p. 6) found out that the key directions of focusing the company's competitive positioning rely not only on desired characteristics in the understanding of consumers and awareness of the "competitive image" of its direct rivals:

However, the obvious feasibility of such a competitive positioning of the enterprise is also not an exhaustive form of system positioning of the enterprise. Its competitive image has one more object of focus, namely, the consciousness of the employees of this enterprise regarding the need to follow a certain competitive behavior. This will prevent unreasonable actions that contradict accepted corporate standards of competition, will save time on the adoption of appropriate managerial decisions, and will help consolidate the desired corporate culture.

Positioning is inherent in differentiation. It means the allocation of such characteristics of products, related services, brand image or company that would distinguish them from competitors. Potential basis of differentiation is the factors that increase the value of products for the consumer, including its psychological satisfaction.

According to M. Porter's classic theory (Porter, 1980 , p. 120-125), a differentiation strategy is a long-term action aimed at providing consumers with products that are of greater value for the same price as competitors. The emphasis is made on creating a product (a set of tangible and intangible attributes) that the consumer perceives as something unique. These may be as follow: design features, performance characteristics of the product, excellent service, a prestigious brand and more. In our opinion, differentiation strategy can be applied not only for goods but also for corporate image development, on a macro basis.

Moving to practical cases of brand positioning, here is an example of six steps for defining the marketing positioning (for goods only) used by the 
consulting firm "PriceWaterhouseCoopers" (PwC Consulting Source, 2008):

1. The main political, economic, social, and technological trends which might have an influence on the market (Macroeconomic Environment Analysis) - PEST Analysis. It is a strategic tool for understanding market growth / decline, potential and direction for operations, the business position.

2. Strengths, weaknesses, opportunities and threats of the CLIENT portfolio (SWOT Analysis CLIENT Portfolio). It is designed for usage in the preliminary stages of decision-making processes and can be used as a tool for evaluation of the strategic position of an organization.

3. Insight into the positioning of the product (Brand Profile - Brand Benefit Ladder). "Ladder" goes from Product/Service attributes though Functional benefits to Emotional benefits (Fig. 1).

4. Insight into the positioning of the competitors selected from each region (Competitor - Competitor Benefit Ladder) (Fig. 2).
5. Insight into the competitors' SWOT versus one's own brands in each region (Competitor Strengths and Weaknesses) (Fig. 3).

6. After considering the competitor's brand benefit ladder together with the SWOT analysis, the brand benefit edge is formulated, summarizing all relevant messages about the brand in a concise statement. For example, "The reliable New Product for (target segment) ... New Product (emotional benefits) is the...Because (functional benefits, attributes) it contains..."

This approach is used for clients ' work for quite some time. Nevertheless, this approach should be changed significantly, because it has some cons due to the fact the global environment is moving forward and using PEST analysis instead of, for example, PESTEL looks quite narrow. Finally, "internet positioning" should be also taken into account. But what is more important here is that the emotional benefits are considered as the top priority for marketing positioning in practice. And for that reason, behavioral factors become more important.

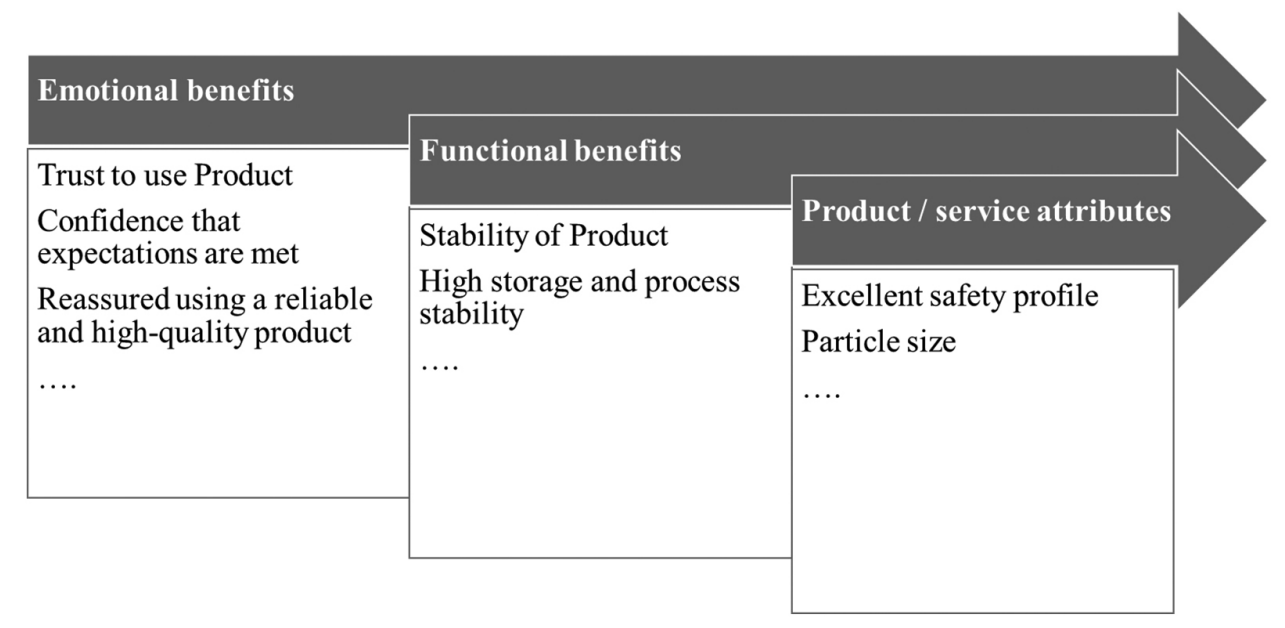

Fig. 1. Brand Benefit Ladder

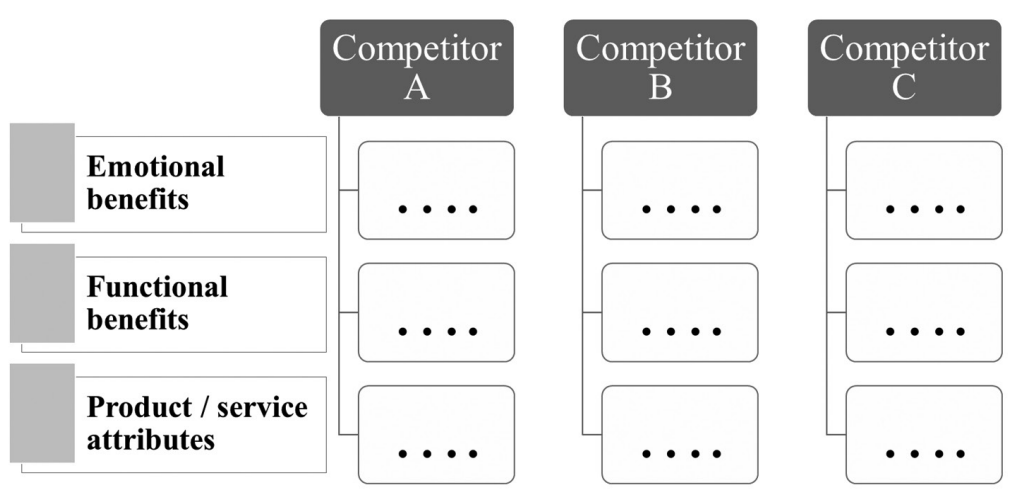

Fig. 2. Competitor Benefit Ladder 


\section{New product}

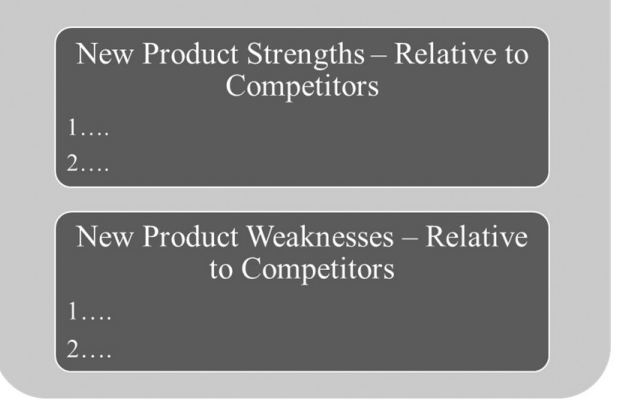

\section{Competitor-A Product}

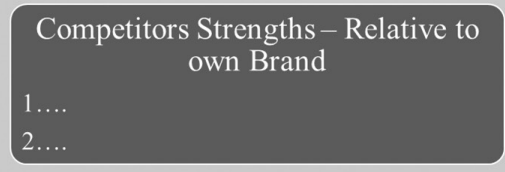

Competitors Weaknesses - Relative to own Brand

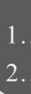

Fig. 3. Strengths and Weaknesses Matrix

And these factors are mostly omitted by scientists when defining competitive positioning.

After analysis of above mentioned information, it is proposed transformation of competitive positioning of enterprise from its narrow meaning as marketing positioning of products to more complex approach. The diagram below (Fig. 4) combines existing concepts of the firm positioning with the new ones.

Conclusions and further research proposals. The competitive positioning of the enterprise is a result of the development and implication of the concept of market positioning of products. In the conditions of complication of forms of competition, intensification of competition, the subject of competitive positioning was not only the product, but also the enterprise that produces it. As a result, competitors and employees of the company joined the objects of competitive positioning, which resulted in the emergence of the concept of behavioral competitive positioning. Therefore, the competitive positioning of the enterprise should be taken as a complex process of creating the desired competitive image in the minds of buyers, competitors and employees of the enterprise.

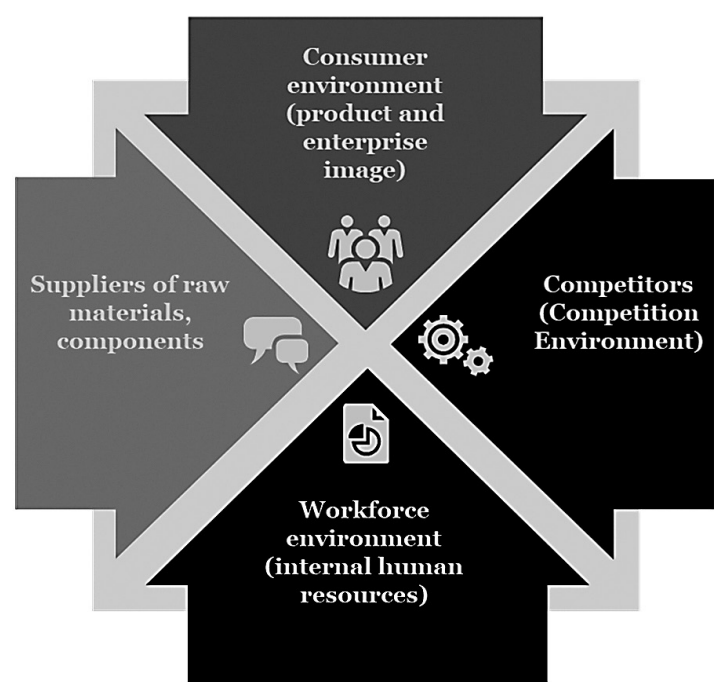

Fig. 4. Objects of competitive positioning

The next step in solving the problem mentioned at the beginning of the article should be to develop a methodological toolkit for selecting and implementing strategies for positioning and evaluating the effectiveness of selected strategies and forecasting the consequences of their implementation.

\section{References}

Aaker, D. A. \& McLoughlin, D. (2010). Strategic Market Management: Global Perspectives. New York: John Wiley and Sons, Ltd. Azoev, G. L., \& Chelenkov, P. (2006). Competitive advantages of a company. Moscow: Typography News.

Doyle, P. (2006). Marketing Management and Strategy (4 ed.). Prentice Hall.

Hooley, G., \& Piercy, N. (2011). Marketing Strategy and Competitive Positioning (5 ed.). Financial Times/ Prentice Hall.

Kotler, P. (2011). Marketing Management: Analysis, Planning and Control. Englewood Cliffs, N.J.: Prentice-Hall.

Porter, M. E. (1980). Competitive Strategy: Techniques for Analyzing Industries and Competitors. New York: Free Press.
Prymak, T. (2012). Strategies of positioning in marketing theory Marketing and Management of Innovations, 1, 13-20. https:// mmi.fem.sumdu.edu.ua/ [in Ukr.].

PwC Consulting Source. (2008). The 12 Elements of Delivery Excellence. pwc.com. https:/www.pwc.com/gx/en/services/ advisory/consulting.html

Ries, Al, \& Trout, J. (2001). Positioning: The Battle for Your Mind. McGraw-Hill Education.

Smolin, I. (2018). Competitive position of the enterprise: contradiction of content, types and destinations. Bulletin of the KNEU. Series Economics, 20(6), 1-10. 
Синиия М. $А$.

\section{КОНКУРЕНТНЕ ПОЗИЦІОНУВАННЯ КОМПАНІЇ: СУПЕРЕЧНОСТІ СУТНОСТІ ТА НОВІ ПІДХОДИ}

У статті проаналізовано деякі ключові визначення та концепції позиціонування бренда за останні 40 років. Наявність багатьох суперечностей ускладнює розроблення повноцінної стратегії фірми і створює плутанину в наукових дослідженнях. Метою статті $є$ систематизація основних підходів до розуміння категорії «позиціонування» та оновлення стратегії позиціонування бренда і підприємства.

Автор обгрунтував важливість комплексного підходу до конкурентного позиціонування підприємства, який спирається не тільки на маркетингове позиціонування його продукції чи самого себе, але й на позиціонування щодо конкурентів та нинішніх (або можливих) працівників. Показано також, що поведінкові фактори (включно з культурними відмінностями) слід враховувати у стратегії позиціонування.

Методами дослідження $є$ описовий, аналітичний, методи синтезу та порівняння. У результаті проведеного аналізу запропоновано комплексний підхід до класифікації стратегій позиціонування на основі систематизації критеріїв створення характеристик товару, марки, підприємства, які відрізнятимуть їх від конкурентів.

Надано кілька пропозицій щодо сучасного погляду на концепцію конкурентного позиціонування, де предметом конкурентного позиціонування $є$ не лише товар, а й підприємство, яке його виробляє. Цю статтю доцільно використовувати для подальшого та глибшого практичного дослідження визначених аспектів конкурентного позиціонування фірми. У результаті проведеного дослідження запропоновано додати конкурентів та працівників компанії до об'єктів конкурентного позиціонування, що зумовлює появу концепції поведінкового конкурентного позиціонування.

Ключові слова: маркетинг, конкурентне позиціонування, стратегія, конкурентоспроможність, бренд, поведінкові аспекти.

Матеріал надійшов 02.05.2020

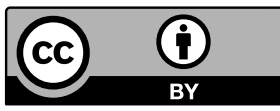

Creative Commons Attribution 4.0 International License (CC BY 4.0) 